\title{
Barroco, hermenéutica y modernidad II
}

\author{
Luis Ignacio Iriarte \\ Universidad Nacional de Mar del Plata \\ iriarteignacio@yahoo.com.ar
}

Fecha de recepción: 27/12/2010, Fecha de publicación: 26/04/2011

<URL: http://www.studiaaurea.com/articulo.php?id=197 >

\section{Resumen}

En la primera parte de este trabajo («Barroco, hermenéutica y modernidad I»), describimos los textos de algunos críticos, escritores e intelectuales del siglo xx que se ocuparon de la cultura europea del 1600. A partir de sus trabajos, distinguimos dos perspectivas: una perspectiva que afirma que existe un retorno del Barroco en la época contemporánea y otra que considera que el Barroco es inseparable del 1600 europeo. Luego extrajimos una serie de ideas compartidas. En esta segunda parte proponemos una mínima reconstrucción histórica de esos ejes de interpretación.

Palabras clave

Barroco, modernidad, prejuicios

\begin{abstract}
:
Baroque and modernity hermeneutics I

In the first part of this work («Baroque and modernity hermeneutics I»), we described the texts of some critics, writers and intellectuals of the xx century who analyzed the 1600 European culture. From their work, we distinguished two perspectives: a perspective that says there is a return of the Baroque in the modern times and another that believes that the Baroque is inseparable from the 1600 European. Then we extracted a set of shared ideas. In this second part we propose a minimal historical reconstruction of these lines of interpretation.
\end{abstract}

Key words

Baroque, modernity, prejudice 
En «Barroco, hermenéutica y modernidad I» partí de la recuperación del Barroco que se dio entre fines del siglo XIx y principios del xx. Aparecieron, por entonces, las importantes lecturas de Heinrich Wölfflin, Werner Weisbach, Walter Benjamin, Eugenio D’Ors, Dámaso Alonso y Alfonso Reyes, entre otros. Según sostuve, en sus textos hay una interacción de dos perspectivas: los autores recién mencionados proponen una reconstrucción de los significados y las estructuras históricas del arte y la literatura del 1600 y a la vez algunos de ellos establecen contactos entre esa época y la contemporaneidad. Hacia mediados del siglo xx, estos lineamientos comenzaron a separarse. Esto no significa una clara divisoria de aguas, sino que lo que existe, más bien, es una acentuación de alguna de las perspectivas puestas en juego. Así, organicé los textos a partir de una «hipótesis del retorno», que considera que el Barroco vuelve en la actualidad, y una "hipótesis historicista», de acuerdo con la cual las singularidades del Barroco son inseparables del siglo Xvir. A pesar de que se diferencian en muchos puntos, todos los críticos y escritores considerados en ese trabajo coinciden en tres ideas básicas: el Barroco es la expresión de una crisis, constituye el nacimiento de la modernidad y el origen del sujeto moderno. Por supuesto, estas ideas no agotan la cuestión. Pero ocupan el centro de la imagen que el siglo xx tuvo de la cultura del xvir. Sin embargo, y en este punto terminó el artículo anterior, estas claves de lectura no aparecieron de golpe al desocultar el pasado, sino que son ejes que los críticos y escritores le impusieron al período, volviéndolo comprensible y asignándole un sentido dentro de la historia. Sugerí, asimismo, que las tres ideas tienen una historia compleja. Puse como ejemplo la palabra crisis. Su significado actual (fin de una época y apertura de una nueva) es muy tardío. Surge en el siglo xx y, para este caso específico, opera como una forma de transformar positivamente la idea de decadencia con la cual los neoclásicos habían condenado lo que nosotros llamamos la literatura del Barroco.

Otro ejemplo, no incluido en la primera parte de este trabajo, se encuentra en la alternancia de Wölfflin entre lo Clásico y lo Barroco. Según Wölfflin, la representación clásica opera en la razón (el pintor representa el mundo tal como debería ser y no según aparece a sus ojos), mientras que la representación barroca se coloca en lo sensorial (el artista muestra el mundo según lo ve, con matices de luz y claroscuros). Esta oposición significó para la época un avance fundamental. En primer lugar, discutió la idea de que el Barroco era un apéndice decadente del Renacimiento y se presentó como un esquema para la comprensión de la historia del arte. En segundo término, sentó las bases para considerar el Barroco como el nacimiento de la modernidad, al menos en lo que respecta al campo de las artes. Pero la oposición entre un período y otro no era nueva. Si pasamos al campo de la literatura, ésta aparece con el neoclasicismo. Como ha insistido la crítica, y en particular se pueden citar las conclusiones de Begońa López Bueno (2005), fueron los críticos y escritores del siglo XviII los que comenzaron a identificar el 1500 como el Siglo de Oro, período fructífero, racionalmente organizado y comparable al de la Antigüedad 
Grecolatina, en oposición a la corrupción y la decadencia de las letras durante el XviI. Por supuesto, entre este primer esquema y las reglas de Wölfflin hay un proceso sumamente complejo. De todos modos, la estructura está puesta en marcha ya desde el 1700 .

En esta segunda parte aspiro a continuar con esta línea. En síntesis, sostengo que la imagen del Barroco que se presenta durante el siglo xx puede comprenderse, en parte, como el resultado de una transformación de las lecturas que habían venido desarrollándose al menos desde mediados del 1700. Para visualizar el mecanismo que, según entiendo, estructura ese proceso, podemos tomar como argumento analógico lo que sucedió con la palabra «barroco». En España, el término es muy tardío. La Real Academia lo registró en 1914 como un adjetivo calificativo. Barroco es, según esa edición del diccionario, «lo irregular por exceso de adornos, y fuera del orden conveniente en arquitectura y artes plásticas». En 1927 se extendió a cierta literatura en la que «predomina la pompa y el ornato». En 1970 se volvió un sustantivo específico para la cultura de los siglos XVII y primera parte del xviII. En Francia hay un comportamiento similar. El concepto comenzó a utilizarse para la pintura a fines del 1700. Sin embargo, como en el uso castellano de 1914, era predominantemente un adjetivo. En su edición de 1743, el diccionario Trévoux «identifica baroque con bizarre y establece que tanto un modo de pensar, como una expresión, como un rostro, pueden ser calificados de barrocos» (Hatzfeld 1964: 493). En 1771 el concepto se especializó para el arte, aunque continuó como calificativo. Sólo a mediados del siglo XIX se convirtió en un sustantivo referido a la producción artística del XVII.

La historia de la palabra no es la historia de lo que sucedió con la cultura a la que ésta se refiere. Pero de ella se puede extraer un argumento central. Antes de adquirir el significado actual, la palabra «barroco» tenía sentidos negativos: irregularidad, extrañeza y deformidad. Cuando pasó a designar el período artístico del siglo XVII, estos significados no desaparecieron. Por el contrario, lo que sucedió es que dejaron de ser estigmas negativos y se convirtieron en marcas positivas. En efecto, los ideales artísticos habían cambiado enormemente desde principios del siglo xIx. La estética de lo feo, que irrumpió con la novela naturalista, y el concepto de grotesco, que Víctor Hugo defendió en el Prefacio de "Cromwell» (1825), habían desplazado los ideales de simetría y equilibrio de la belleza, preparando el terreno para la valorización de la irregularidad, la extrañeza y la deformidad. En otros términos, la reivindicación del Barroco no fue el resultado de un simple desocultamiento de la verdad, escondida durante mucho tiempo debajo de una serie de prejuicios injustificados. Más bien habría que ver el proceso como una progresiva resignificación de esas ideas negativas.

Los prejuicios fueron extensamente tratados y discutidos. En "Algunas consideraciones sobre los procesos de canonización en la preceptiva literaria» (2005), José Manuel Rico propuso la importante idea de que, aparte del canon de los autores, existe también un canon de juicios estéticos nacidos en el siglo 
xvir. Por ejemplo, según señala el crítico, la idea de la decadencia de la literatura española comenzó a fraguarse en la polémica en torno a Góngora y luego pasó a constituir «la piedra angular sobre la que se edificó la crítica literaria de los siglos XVIII y XIX» (2005: 158). Pero los críticos contemporáneos condenaron este tipo de juicios canonizados. Para el propio Rico, son «ideas mostrencas que se han venido repitiendo de forma acrítica y, por tanto, asumidas sin reservas, hasta la historiografía literaria del siglo XX» (158). Por el contrario, lo que me propongo sostener en este trabajo es que esos prejuicios cumplieron un papel importantísimo en el rescate del Barroco. Como se acaba de sugerir a partir de Víctor Hugo, no sólo hubo un cambio de actitud hacia la cultura del siglo XviI, sino que esto estuvo acompañado, e incluso impulsado, por una valoración positiva de los prejuicios canonizados.

En la bibliografía existen innumerables ejemplos que abonan esta tesis, a pesar de que sus autores buscan otro tipo de respuestas. Uno de ellos se encuentra en "Barroco: categorías, sistema e historia literaria» (1993). En el primer párrafo, Víctor García de la Concha observa que, en el Diccionario de la música, Jean-Jacques Rousseau había presentado una imagen profundamente negativa del Barroco al señalar que se trata de un tipo de música confusa, disonante y artificial. Ese sentido peyorativo, según argumenta, persiste hasta Benedetto Croce, quien señala, en Storia dell'eta barocca in Italia (1929), que en este prejuicio "late una concepción formalista» (1993: 59). Pero, continúa el crítico, es importante recordar que Wölfflin retomó este formalismo y le dio un vuelco al asunto, en tanto pasó a considerar que «no se trata, según él, de analizar la belleza sino el elemento en el que un determinado tipo de belleza ha tomado forma» (59). A pesar de que García de la Concha deja de lado el argumento, surge de su análisis que la reivindicación del Barroco tiene tanto que ver con un nuevo examen del período como con una reconsideración del concepto de forma.

Otros ejemplos se encuentran en El barroco de los modernos (2009) de Aurora Egido. Con un gran apoyo documental, Egido plantea que, durante las primeras décadas del siglo xx, se produjo una verdadera invención del Barroco. Las múltiples imágenes que proporcionan los autores de esa época están estructuradas a partir de dos ejes: la centralidad de Góngora, que desplazó por el momento a otros autores, y la importancia de las artes plásticas, campo en el que emergió por primera vez una revalorización, por cierto que de la mano de Wölfflin, lo cual supuso una concepción del Barroco en la que ocupan un primer plano «cuestiones formales y sensoriales, marcadas a su vez por la impronta del Modernismo» (2009: 7). Pero lo que quisiera destacar, en este contexto, es menos la invención que la transformación de los viejos prejuicios. Así, por ejemplo, Egido sostiene que Antonio Machado descalificó el Barroco a través de una defensa de valores fundamentalmente románticos, basados en la sinceridad y en la expresión de emociones. Pero «lo que Machado negaba al Barroco se convertía en moneda de cambio para la joven poesía, que desdeña- 
ba los presupuestos románticos a la par que los neoclásicos y se movía en un terreno distinto al suyo" (54). En otras palabras, los poetas del '27 aceptaron los juicios de Machado, pero les dieron de golpe un perfil positivo. Otro tanto se encuentra en el capítulo que Egido le dedica a Dámaso Alonso: «Para él, las Soledades destacaban precisamente por aquellos valores que se censuraron en su tiempo, vale decir, la falta de asunto, que corría en paralelo con la novela del primer cuarto de siglo» (215). Al igual que antes, Alonso acepta los prejuicios nacidos con el neoclasicismo, pero los comprende como valores positivos. En este sentido, si por un lado se puede hablar de invención del Barroco, por el otro debemos tomar en cuenta que la invención también es el resultado de un largo y complejo desplazamiento conceptual.

Podemos comprender este corrimiento a partir de algunas consideraciones de Hans-Georg Gadamer. En Verdad y método (1960), el filósofo discutió la descalificación de los prejuicios de la Ilustración. Independientemente de su verdad o falsedad, para Gadamer los prejuicios constituyen ideas clave a partir de las cuales le damos significación a los textos. Conforman, en otros términos, lo que llamamos la tradición: los heredamos del pasado y los utilizamos como esquema básico de interpretación. Pero la lectura de los textos puede producir cambios en las ideas globales. Para Gadamer, este círculo hermenéutico, que va del todo a la parte y de la parte al todo, nunca se detiene. Asimismo, como el lector está inmerso en la tradición, cada lectura no sólo cambia sus prejuicios, sino que, si tiene impacto en las instituciones culturales, transforma también la tradición colectiva. A partir de esto, como una forma de comprender el proceso de conformación del Barroco, se puede plantear, al lado de la «hipótesis del retorno" y la "hipótesis historicista», una "hipótesis hermenéutica». De acuerdo con esta perspectiva, la imagen contemporánea del siglo XVII es el resultado de un largo desplazamiento conceptual, que puede comprenderse a partir de la imposición de prejuicios globales y de las operaciones de lectura que existió sobre ellos. Este proceso es el responsable de la instauración de las ideas de nacimiento de la modernidad, época de crisis y origen del sujeto moderno, claves para la imagen del Barroco que operó a lo largo del siglo xx.

Si bien esta hipótesis necesita una larga demostración, en esta segunda parte voy a referirme solamente a algunos tramos de la historia. En cada uno pongo el énfasis en un autor, pero a la vez comprendo el lugar que la época a la que éste pertenece le asigna a la literatura del siglo Xvir. El punto de partida es la imagen que establecieron Ignacio de Luzán y, secundariamente, algunos otros neoclásicos. El trabajo pasa luego a considerar la revalorización del teatro por parte del romántico Agustín Durán y otros críticos del siglo XIx. El repaso de esta historia concluye con Rubén Darío y la época del modernismo. El proceso puede resumirse en dos puntos: el neoclasicismo desplaza la literatura del siglo XVII a los márgenes de la razón y, con el romanticismo y el modernismo, este estigma se va convirtiendo en un rasgo positivo. Como veremos, la invención del Barroco es el resultado de este proceso. Empecemos, por lo tanto, con Luzán. 


\section{Una poesía irregular}

Sobra decir que a estas alturas se han realizado importantes trabajos sobre el siglo XviII como para que sea necesario establecer una descripción prolija. Podemos recuperar algunos sentidos básicos a partir del clásico trabajo de Guillermo Carnero «Los dogmas neoclásicos en el ámbito teatral» (1994). Para el crítico, los neoclásicos propusieron tres dogmas. En primer lugar, abrazaron la tradición de la Antigüedad grecolatina, la razón y las exigencias de la psicología del destinatario e impulsaron unas reglas y una concepción de la poesía universal, válida para cualquier tiempo y cualquier lugar. En segundo término, "creyeron que su época estaba llamada a realizar, entre otras cosas, una reforma de los usos y comportamientos sociales» (1994: 41), para lo cual revivieron el delectare et prodesse. Por último, comprendieron la necesidad de «las motivaciones irracionales e innatas a las que se da el nombre de inspiración» (45), pero a la vez destacaron la importancia "de una técnica, racional y adquirida por la reflexión y el estudio, y que comprendía el arte y la ciencia» (42).

Ignacio de Luzán publicó la Poética en 1737 y, mucho después de su muerte, apareció una segunda edición, con modificaciones, en 1789. El volumen, que suele considerarse como el comienzo del neoclasicismo, contiene ya de manera muy nítida los dogmas a los que se refiere Carnero. Este hecho se hace evidente a partir de la lectura que Russell Sebold propone en la edición de 2008. Según sostiene el crítico, Luzán tuvo una formación ecléctica. En la Poética todavía se registran algunos argumentos basados en la apelación a las autoridades. Pero incluso cuando se respalda en una figura tan importante para la escolástica como Aristóteles, Luzán se preocupa por encontrar, suplementariamente, razones fundadas. En muchos pasajes se advierte además una explícita influencia del empirismo inglés. Pero, más claramente aún, la obra de Luzán se inscribe en la línea de la gramática de Port-Royal y por consiguiente en la filosofía cartesiana (Sebold 2008). La estructura global de La poética responde a esta última perspectiva. Luzán comienza con las ideas generales y procede por deducción hasta llegar a los conceptos particulares. El título completo (La poética o reglas de la poesía en general, y de sus principales especies) ostenta ese cartesianismo. Otro tanto se comprueba al recorrer la obra. Dividida en cuatro libros, en el primero escribe sobre el «origen, progresos y esencia de la poesía", en el segundo sobre la utilidad y el deleite, y los últimos dos los dedica a los géneros particulares, trabajando en uno la poesía dramática y en el otro la poesía épica. Defiende, en fin, la universalidad de las reglas: «Una es la poética y uno el arte de componer bien en verso, común y general para todas las naciones y para todos los tiempos» (174). Pero la centralidad que le confiere al racionalismo cartesiano no desmiente su formación ecléctica. Luzán propone una poética racional, basada en la imitación de la naturaleza y el equilibrio y la mesura de los recursos, con el propósito de restaurar el buen gusto, corrompido durante el 1600. Para esto se inscribe en la filosofía cartesiana y, 
según le conviene, hecha mano también del empirismo y se apoya en algunas citas de autoridad ${ }^{1}$.

En relación con el siglo XviI, la obra de Luzán puede considerarse como un llamado al orden a través de un fuerte alegato a favor de una poética racional. Esto se percibe en esta notable comparación que propone para hacerle comprensible al lector sus severos juicios sobre los poetas dramáticos españoles:

Si alguna expresión o censura, especialmente sobre las comedias de Calderón y Solís, te pareciere demasiadamente rígida, yo querría que te hicieses cargo de que, o no hago más que referir lo que otros han dicho, o que, tal vez, me sucedía a la sazón lo que a Horacio cuando veía dormitar a Homero; o que, finalmente, pasa en nuestro caso lo mismo que en un motín popular, en cuyo apaciguamiento la justicia suele prender y castigar a los primeros que encuentra, aunque quizá no sean los más culpados (120-121)2.

Este llamado al orden (represión de la razón contra los autores no encuadrados en ella) se basa en un estudio de las facultades mentales del hombre que es importante destacar. Como señala Carnero, Luzán comprende que la poesía requiere de la colaboración de los componentes no racionales de la inspiración y de los componentes regulativos de la razón. En los capítulos XI y XII del segundo libro ahonda esta perspectiva a través de un uso explícito del empirismo. En esos tramos, Luzán divide las facultades del espíritu en fantasía, ingenio y juicio: «Las dos primeras potencias son como los brazos del poeta, que hallan materia nueva y maravillosa, o la hacen tal con el artificio; el juicio es como la cabeza, que las preserva de excesos» (272). En Luzán, el ingenio es la «fuerza activa con que el entendimiento halla la semejanza, las relaciones y razones intrínsecas de las cosas» (327). Pero el verdadero eje de este análisis del alma se encuentra en la interacción entre la fantasía y el entendimiento.

Para abordar este tema, Luzán se apoya en John Locke. Los objetos sensibles, según sostiene, «introducen en nuestra alma una imagen o copia de sí mismos, la cual imagen [...] se imprime y dibuja en el celebro o en otra parte donde el alma ve y comprehende esas imágenes» (277). Luzán sostiene que hay dos facultades que se ocupan de estas representaciones: la fantasía, o «aprehensiva inferior», y el entendimiento, o «aprehensiva superior». En principio, parece su-

1. El mismo cartesianismo y el mismo propósito moral se encuentran en la manera mediante la cual comprende que deben crearse los argumentos. Luzán retoma a Le-Bossu y sostiene que «primeramente es menester empezar por la instrucción moral que se quiere enseñar y encubrir bajo de la alegoría de la fábula» (495). En este sentido, propone que el poeta debe hallar ideas morales, claras y distintas, para luego recubrirlas con el material que le proporciona la imaginación. 2. Vale recordar que Luzán no tomó como blanco de sus críticas a Calderón de la Barca, porque en general lo considera un poeta notable, independientemente de las desviaciones que le marca respecto de las unidades teatrales. Pero sí es sumamente severo con Góngora y Lope de Vega y a partir de ellos propone una imagen general de la poesía del siglo XVII. 
gerir que la fantasía es la pizarra en la que se imprimen las representaciones que provienen de los sentidos, mientras que el entendimiento es el sistema racional que opera sobre ellas. Pero poco después, al hacer interactuar las dos facultades, le da a la fantasía una mayor autonomía. En efecto, Luzán distingue tres tipos de operaciones. Según la primera, el entendimiento concibe imágenes sin que la fantasía aporte otra cosa que impresiones mínimas tomadas de la experiencia, como cuando, a partir de varios casos, producimos generalizaciones; de acuerdo con la segunda, hay un trabajo conjunto de las dos facultades, cosa que sucede cuando la fantasía, conducida por el entendimiento, une y separa las sensaciones formando imágenes nuevas; en la tercera, la fantasía usurpa las riendas al entendimiento y manda despóticamente en el alma. Este tipo de operaciones le provocan una reflexión, sumamente importante y que es necesario citar:

semejantes imágenes, hijas de una loca y desenfrenada fantasía, en las cuales todo es falsedad, desorden y confusión, no caben en la poesía, ni aun en los discursos de hombres de sano juicio, dejándose sólo para los que, o dormidos sueñan, o calenturientos desvarían, o enloquecidos desatinan (278).

Estas tres operaciones cambian la impresión inicial de lo que es la fantasía y el entendimiento. En principio, Luzán parecía referirse a la primera como la pantalla en la que se imprimen las representaciones de las cosas y el entendimiento era un sistema que operaba sobre ellas. Pero como se ve en este pasaje, la fantasía tiene una gran autonomía. No es un mero receptáculo de impresiones, sino una facultad que opera sobre ellas, combinándolas entre sí, con total libertad y desorden. La mención de los sueńos es sumamente importante en este contexto. En ellos hay imágenes que se combinan con libertad y aparentemente sin lógica alguna. En consecuencia, el entendimiento funciona como una facultad de regulación. Aporta un esquema racional para discernir, separar y comparar esas combinaciones libres. En este sentido, es un aparato de gobierno, regulación y conducción.

Según Luzán, las obras literarias pueden comprenderse a partir de estas tres operaciones. El empleo exclusivo del entendimiento da como resultado la filosofía y las preceptivas. Los otros dos tipos de operaciones explican la existencia de obras poéticas buenas y malas. Son buenas todas aquellas en las que las imágenes que proporciona la fantasía son gobernadas por el intelecto. Éstas no se reducen a la imitación simple de la naturaleza. La poesía debe representar las cosas como son (una batalla o una tormenta), pero también como pueden ser (los amores de Dido y Eneas) o como podrían ser, caso este último en el cual se presenta una verdad, la belleza de un prado, utilizando metáforas mediante las cuales se lo describe como una mujer hermosa. La mala poesía, en cambio, es aquella que se aproxima al gobierno exclusivo de la fantasía. Como vimos en las palabras antes citadas, Luzán considera que esto únicamente se produce durante el sueño y en la locura. Pero este parámetro absoluto funciona como punto de referencia. En 
este sentido, la mala poesía es aquella que reduce el ámbito de gobierno de la razón y por consiguiente se acerca al desenfreno.

La imagen del pasado que Luzán propone se basa en estas consideraciones. Para la Poética, la poesía del siglo Xvi se ajustó perfectamente al trabajo conjunto de la fantasía y el entendimiento. Luego, sobre todo con Góngora y Lope de Vega, ese equilibrio se desmoronó. Para Luzán, el primero tuvo un gran ingenio y fantasía. Incluso le parecen rescatables las obras menores. Pero se descarrió en los poemas extensos, «usando sin medida un estilo sumamente pomposo y hueco, lleno de metáforas extravagantes, de equívocos, de antítesis, de retruécanos y de unas transposiciones del todo nuevas y extrañas en nuestro idioma» (172), creando en consecuencia una poesía incomprensible, que el "vulgo» aplaudió porque eso es a lo que se ha dedicado desde siempre: a festejar e imitar aquello que no entiende de ninguna manera. Este tipo de juicios no eran nuevos. Como sugiere Rico (2005), Luzán continúa las críticas que Góngora se había ganado en vida. Lo nuevo se encuentra, en cambio, en el sistema en el cual encasilla esa censura. En Góngora, según Luzán, se impuso la fantasía en desmedro del entendimiento. Así, lo considera el gran ejemplo de «cuán disformes monstruos puede concebir una fantasía desordenada y en qué derrumbaderos puede caer» (313).

Aunque destaca muchos más aciertos en Lope, sus obras le merecen juicios igual de severos. Primero le dedica una semblanza biográfica y luego destaca que, como Góngora, tuvo un talento irrepetible. Pero alcanzó la madurez durante el desordenado siglo Xviı y se perdió en los meandros del mal gusto. Para peor, la combinación entre su talento, la facilidad en la escritura y el mal gusto de la época lo llevó, según Luzán, a ahondar la decadencia general. Esto se debe a que sus numerosísimas obras, celebradas por el público, influyeron decididamente en los otros escritores, lo cual llevó a los nuevos dramaturgos a tomarlo como modelo. Escribe al respecto Luzán, en la mucho más severa edición de 1789:

La fantasía de un poeta enamorado, exagerando en la violencia de su pasión la hermosura de su dama, la llamará tal vez metafóricamente sol; sobre esta metáfora fundará después un sofisma y querrá probar seriamente que, aunque el sol verdadero tramonte, no por eso anochece, porque su sol metafórico está presente. De semejante modo argüía Lope de Vega Carpio (319-320).

Pero a Lope no le reprocha el desvarío, según el tipo de juicios que emite sobre Góngora, sino su adhesión enfermiza al público. En efecto, Luzán le critica menos la fantasía descarriada que el haber incurrido en ella para lograr el éxito:

Este error -observa, tomando como ejemplo a Lope- es común a muchos poetas, no sólo españoles, pero también de otras naciones, los cuales, viendo que lo maravilloso, lo extraordinario y lo inopinado es muy aplaudido en la poesía, y no sabiendo, o por pereza o por ignorancia, el modo de hallarle entre la verdad 
o la verosimilitud, recurrieron, como a medio más fácil, a una maravilla falsa y a unas paradojas fundadas en equívocos y derivadas de las suposiciones y ficciones de la imaginación poética. Entre el vulgo ignorante, y, especialmente, entre aquellos que no penetran hasta el fondo de las cosas, contentándose con la superficie, estas paradojas aparentes y estas falsas maravillas, con la doradura superficial y aquella exterior brillantez que ostentaban, lograron ser tenidas por verdadera belleza y por uno de los más hermosos y exquisitos adornos de la poesía, bien así como entre nińos o entre simples villanos se estiman los biriles como diamantes y el oropel como oro (319).

Con estos juicios sobre dos de los escritores centrales del período, se impuso durante el neoclasicismo una imagen sumamente negativa de la literatura del siglo Xvir. Como recuerda José Berbel Rodríguez (2003), Ignacio de Luzán, Blas Nasarre, Agustín Montiano y Luyano y Luis Velázquez, entre otros, propusieron la teoría de que, frente a la Antigüedad clásica y el equilibrio y buen gusto alcanzados durante el siglo xvi, el 1600 llevó a la poesía a la corrupción. Debido a la insistencia del primero en el componente de la fantasía y la idea de que ésta no debe separarse del intelecto, tenemos la tendencia natural a comprender este prejuicio neoclásico a partir de lo irracional, como lo opuesto a la razón. Pero los neoclásicos no emplearon esa palabra. En Origenes de la poesía castellana (1754), Velázquez utiliza «desorden», «mal gusto», "gusto depravado», «extrańo»y, para identificar el rol de Lope, señala que éste vino a «corromper» o a «viciar» la poesía. Entre estas palabras, el «desorden» se ajusta perfectamente bien a los reproches de los neoclásicos, en tanto no sólo significa "falta de orden», sino también «exceso». Si tomamos en cuenta que, en el Diccionario de autoridades, «racional» se define como «Lo que toca o pertenece a la razón, y es arreglado a ella», el antónimo más preciso es «irregular», es decir, «lo que es fuera de regla, o contrario a las reglas de algún arte o gobierno».

En suma, el neoclasicismo comprendió la poesía del siglo XviI como un desborde de la razón. En Lope y Góngora hay exceso, desorden, desarreglo, todas cuestiones que se explican porque se apoyaron desmedidamente en la fantasía.

\section{Teatro y genio nacional}

El neoclasicismo propuso una serie de valores mediante los cuales restaurar el gusto de la poesía. Ésta debía imitar la naturaleza, instruir al público con ideas claras y distintas y ordenar la inspiración con la razón. A partir de este sistema, Luzán planteó al menos cuatro ideas sobre la literatura del siglo xvir. Se trata de una poesía anticlásica, inverosímil, que se subordina a los gustos del pueblo y desborda el marco de la razón. La actitud que tomó el romanticismo no puede separarse de esta lectura. Cuando los románticos valoraron positivamente el teatro del siglo XVII, no lo hicieron porque consideraran que los neoclásicos estuvieran equivocados, sino porque estas cuatro ideas cobraron valores positivos. Para ellos, el teatro 
inaugurado por Lope era valioso precisamente porque se encontraba en los márgenes de la razón y era anticlásico, inverosímil y popular.

Este desplazamiento puede comprenderse a partir del binomio razón/fantasía. Como señala Guillermo Serés, desde mediados del siglo XviII comenzó a jerarquizarse la fantasía y, por consiguiente, a depreciarse el valor de la razón: «en germen está la progresiva sustitución de la realidad y su visualización en el sentido aristotélico por el proceso imaginativo-creativo del poeta» (1994: 229). Tomando un ejemplo significativo en este contexto, sostiene que "Blanco White [...] apunta que la poesía es el lenguaje de las pasiones; el poeta ha de experimentar el mundo pero a través de su propia conciencia» (229). En «Lo gótico, lo funeral y lo macabro en la cultura española y europea del siglo xviII», Nigel Glendinning propone un interesante panorama que permite complementar esta idea. Según argumenta el crítico, los neoclásicos rechazaron el estilo gótico. Ese estilo era primitivo «y sus edificios llenos de quimeras, harpías, ornamentos grotescos e irracionales, imágenes burdamente esculpidas y amontonadas sin sentido de unidad ni armonía» (1994: 120). Aunque Glendinning no lo menciona, este tipo de juicios está presente en el Origen de la poesía castellana. En ese texto, Velázquez señala que, cuando los godos invaden España, se empieza a perder el gusto de la poesía latina, «degenerando ésta de aquella gracia y nobleza con que los Españoles la habían recibido de los Romanos» (1797: 12-13). Así, en Velázquez lo gótico se identifica con «corrupción», «degeneración», «rudeza»y «barbaridad». Pero, de acuerdo con Glendinning, a fines del siglo XviII comienza un proceso de revalorización. Lo inverosímil del gótico, que antes se identificaba con el desorden y el error, se va vinculando con lo Sublime y comienza a ocupar el centro del sistema literario.

Aunque su interés está centrado en el siglo XviI, Agustín Durán es un gran representante de este proceso. Su contribución más importante es el Discurso sobre el influjo que ha tenido la crítica moderna en la decadencia del Teatro Antiguo Español, publicado en 1828. Como se sabe, el propósito de ese texto es criticar la preceptiva neoclásica y rescatar la poesía dramática del siglo XVII. Esto no significa, según se dijo, que discutiera los prejuicios de Luzán. Por el contrario, acepta que el teatro de Lope es anticlásico, popular, choca contra el precepto de la imitación de la naturaleza y está situado en los márgenes de la razón. Pero transforma la valoración de esas ideas a partir de una defensa del componente sentimental de la poesía en detrimento del racional. En una nota a pie de página, Durán sostiene que un hombre dedicado exclusivamente a las matemáticas no puede valorar las obras de imaginación, del mismo modo que a aquel que está habituado a la poesía le resulta incomprensible el razonamiento de los axiomas y las ecuaciones. El primero «dirá que la poesía nada prueba, y el otro sostendrá que el cálculo fastidia. Mas ninguno tendrá absolutamente razón, aunque la tengan relativamente». Para Durán, «El uno debía decir, que no siente las bellezas de la imaginación, y el otro que no conoce ni entiende las abstracciones del cálculo» (1828: 49-50). Así, la poesía pertenece al componente imaginativo y sentimental. 
Esta nueva comprensión de la literatura está íntimamente ligada a una reconsideración de los vínculos entre lo clásico y lo moderno. Para Durán, son dos épocas totalmente diferentes y por lo tanto incomparables. Rompe así con la idea de que las reglas de la poesía son universales y resignifica positivamente la propuesta de que el siglo XviI fundó una literatura anticlásica. Pero lo verdaderamente importante es que la segmentación entre una cultura y otra no se basa en cuestiones racionales, sino en el «genio nacional», concepto nuevo que significa «modo de ver, sentir, juzgar y existir» de los habitantes de una nación (Durán 1828: 13-14). El eje de esa idea se encuentra en lo sentimental y no en lo racional. Esto no sólo surge de las palabras recién citadas, sino del hecho de que la cultura clásica y la que nace con la Edad Media se organizan alrededor de dos sentimientos religiosos claramente diferenciados.

Para Durán, la religión antigua tiene una presencia concreta en el mundo. El hombre griego percibe una mutua imbricación entre el mundo sagrado y el profano, como se advierte en que las mitologías y las teogonías son personificaciones de las fuerzas naturales. La Edad Media cambió definitivamente esta situación. Frente a la religión antigua, el cristianismo colocó en el alma de los hombres una dimensión espiritual inalcanzable, situando en el más allá de la comprensión la dimensión sagrada de la creación y el gobierno universal. Escribe en este sentido Durán:

¿Qué imaginación, aun la más perspicaz, podrá abarcar la inmensa distancia que media entre las creaciones poéticas, inspiradas por tan sublime creencia, y aquellas a que se presta la mitología gentilicia? En esta todo se personifica y materializa, en aquella es todo espiritual e indefinible: en la una todo se ve y es palpable, en la otra todo es fe, e idealidad: allí la hermosura, la guerra y la ciencia eran entes personificados, y aquí cuantos bienes y males reinan en el Universo, son distribuidos por una sabia providencia para provecho de los hombres (1828: 64).

Según Durán, esta transformación produjo un cambio en la creación estética. En el mundo grecolatino, con una religión que no era otra cosa que la personificación de las fuerzas naturales, la representación artística no se enfrentó nunca con algo fuera del horizonte de los sentidos. En la escultura, la lírica o el teatro el hombre debía disponer de manera armónica los elementos visuales con los que personificar el contacto directo con los dioses. El cambio medieval no puede ser, en este aspecto, más profundo. El hombre dejó de entender el arte en función de la simetría y la armonía del mundo visible. Con esto, Durán ratificó los prejuicios neoclásicos, volviéndolos positivos. El cristianismo tiene como consecuencia el abandono de las reglas de la Antigüedad, tanto porque las unidades aristotélicas responden a un tipo de arte cuyo propósito es ofrecer una imagen clara y equilibrada de los dioses, como así también porque el absoluto carece de jurisprudencia y es inexpresable con la razón y el lenguaje. Asimismo, si es positivamente anticlásico y está basado en los sentimientos, la nueva religión obliga al arte a abandonar el precepto de la imitación de la naturaleza: «El verdadero entusiasmo procede del éstasis y arrobamiento del alma, que desprendiéndose de las trabas 
del mundo real o prosaico, se eleva a las ideales regiones de la belleza poética» (24). Esto lo lleva a criticar el precepto neoclásico de la imitación: «La noble poesía arrastraba las cadenas de la servil e indirecta imitación de la naturaleza, sin atreverse a sacudir el ominoso yugo que la oprimía e impedía alzar su vuelo libre y desembarazado a las regiones de la imaginación» (56).

Igual de importante es el vínculo de los dramaturgos con los gustos populares. Como vimos, Luzán rechazó esta perspectiva en lo que respecta a los escritores del siglo Xvir. Para él, las reglas surgen de la razón universal. Por eso son las mismas en todo tiempo y lugar, de modo tal que cualquier diferencia debe entenderse como un error. Durán da la vuelta a este planteo. En el siglo XVII «se creó nuestro teatro, formando la portentosa y admirable reunión de tantos medios poéticos y sublimes como van dichos. Desde Lope de Vega a Calderón fue cada día perfeccionándose y aumentándose el brillo de nuestro drama» (12). Durante esa época, los dramaturgos alcanzaron una literatura que estuvo en condiciones de expresar el espíritu nacional. Para demostrarlo, el crítico retoma el Arte nuevo de hacer comedias para comprobar la dialéctica entre gustos populares y genio creador. Desde un punto de vista opuesto al de Luzán, Durán destaca que en ese texto Lope comprende perfectamente bien las características de las reglas clásicas, razón por la cual le parece aún más valioso que se ajustara a las exigencias del público: «Fue pues el gusto del público, y no la ignorancia o la propia voluntad, el que obligó a nuestros dramáticos del siglo diez y seis y diez y siete a abrirse camino por donde marcharon con tanta gloria suya como admiración de los extranjeros» (45).

Con esto, Durán le imprimió un nuevo significado al teatro del siglo XviI. En el Arte nuevo, Lope habla de los gustos del vulgo. Con esas palabras se refiere al público que asiste a los corrales. Observa que el vulgo prefiere obras que no se ajustan a las unidades y a las reglas clásicas, por eso él mismo se desentiende de ellas («como las paga el vulgo, es justo/ hablarle en necio para darle el gusto» (1971: 285)). Durán sobrescribe ese texto. En donde dice vulgo lee genio nacional, nuevo prejuicio que tendrá un lugar de primer orden para la crítica, que considerará el siglo XVII como el nacimiento de las tradiciones nacionales.

En síntesis, Durán ratifica los prejuicios del neoclasicismo, pero invierte su valoración. Para él, la literatura nacida con la Edad Media, que llega a su esplendor con el teatro del siglo XvII, es positivamente anticlásica, no mimética, popular y su eje es el sentimiento religioso y el modo de ser de lo nacional.

\section{Cambios en la teoría de la corrupción}

Mención aparte merece la teoría de la corrupción. Como vimos, los neoclásicos entendieron que, tras el equilibrio logrado en el siglo Xvi, los poetas habían ido abandonando la conducción racional y, por lo tanto, corrompieron el buen gusto. Algunos críticos del 1800 ratificaron esta idea, pero le impusieron grandes 
transformaciones. En un primer momento, las responsabilidades se desplazaron hacia Góngora y sus seguidores, absolviendo de este modo a los autores dramáticos. En un segundo tiempo, y según el proceso de jerarquización de lo no racional, la decadencia empezó a explicarse a partir de una acentuación desmedida del estudio y la erudición, aspectos que sepultan o asfixian el alma del poeta.

El corrimiento hacia Góngora se encuentra plenamente en Durán. En su texto propone una historia de la literatura española que permite esclarecer este tema. Según Durán, ésta nace durante la invasión mora. La refinada cultura árabe le permitió a España sobresalir respecto de una Europa que por entonces «se hallaba aún sumergida en las tinieblas de la ignorancia» (8-9). El prestigio de las escuelas diseminadas en Toledo, Córdoba y Sevilla, en las que se ejercitaba la ciencia, la metafísica y la poesía, convocó a los trovadores nacidos en el mediodía francés. Resonaron en suelo ibérico las canciones amorosas de la poesía provenzal. Hasta que «al fin los trovadores catalanes y aragoneses se vinieron a la corte del castellano Juan II, a mezclar y confundir la melodía sentimental y melancólica de su poesía, con la rica y ferviente imaginación de los moros andaluces» (10). Para Durán, España se formó de esta mezcla entre los pueblos del Norte y los del Oriente. Su poesía es «el amalgama modificado de la de aquellos pueblos» y esto es lo que singulariza el carácter español: «Sin ser [la poesía] tan exacta y filosófica como la de los franceses, es mucho más rica, brillante y fluida; y sin ser tan audaz y exagerada como la de los árabes, es más verosímil y razonable» (10-11). Para coincidir con el alma nacional, la poesía española, según Durán, debe ser el término medio, la síntesis de la racionalidad de Francia y la audacia y la exageración mora.

Garcilaso de la Vega es el primer gran representante de esta conjunción. Según Durán, el gran poeta toledano reunió las formas métricas de la poesía italiana, la expresión sencilla y sentimental de los pueblos del norte y la vehemente y lírica imaginación de los orientales. Luego llegó el esplendor del teatro nacional. Como vimos, Durán propone la importante tesis, que más tarde se vuelve prejuicio interpretativo, de que Lope llevó a su esplendor la conjunción entre el arte y los gustos populares. La misma idea le sirve para comprender el gongorismo y el neoclasicismo. Según se deduce de su texto, Góngora es una inclinación arábiga de la poesía española, desviación que a fines del siglo XvII contaminó también el teatro. De acuerdo con la misma lógica se puede comprender su rechazo del neoclasicismo. En efecto, si bien entiende que el acento en la racionalidad es una reacción contra el mal gusto, al mismo tiempo considera que se trata de un vicio igual de condenable, porque no responde al alma española. Para un pueblo racional como el francés, la doctrina clásica es una expresión natural. Pero en España esa perspectiva significa una abusiva desviación respecto del genio nacional.

En Durán, la teoría neoclásica de la corrupción se desplaza hacia Góngora y sus seguidores. Pero al explicar las causas a partir de la abusiva inclinación hacia la raíz mora, continúa considerando que la decadencia se debe a una liberación 
condenable de la fantasía. Tras Durán, esta propuesta empieza a cambiar. Los componentes no racionales continúan ganando el centro del pensamiento literario y por consiguiente la decadencia comienza a comprenderse como una acentuación desmedida del estudio y la erudición. El primer texto que se puede citar, en ese sentido, es Poetas líricos de los siglos XVI y XVII, que Adolfo de Castro publicó en la Biblioteca de Autores Españoles de Rivadeneyra en 1854.

En esa antología, Castro dedica un importante espacio a Góngora. Si bien en sus comentarios señala varios hallazgos en la obra del poeta cordobés, el erudito no se aparta de la lectura a la que lo empujaba la época. Así, distingue la claridad que el poeta había alcanzado en los romances, las letrillas y los poemas sencillos, separándola de lo que también él considera como los errores imperdonables del Polifemo y las Soledades. Para esto, en la colección de juicios con los que presenta a Góngora, repone un tramo de la famosa carta de Lope de Vega, en la cual éste separa los romances y las obras sencillas de lo que el poeta se propuso luego, con el Polifemo y las Soledades. Escribe Lope en el pasaje seleccionado por Castro:

Tenemos singulares obras suyas en aquel estilo puro, continuadas por la mayor parte de su edad, de que aprendimos todos erudición y dulzura, dos partes de que debe constar el arte. Mas no contento con haber hallado en aquella blandura y suavidad el último grado de la fama, quiso, a lo que siempre he creído, con buena y sana intención, y no con arrogancia, como muchos que no le son adeptos han pensado, enriquecer el arte y aun la lengua con tales exornaciones y figuras cuales nunca fueron imaginadas ni hasta su tiempo vistas $(1854: 425)^{3}$.

Castro, que incluye en su antología las Soledades y el Polifemo, toma como esquema de lectura esta segmentación de Lope de Vega. Así, concluye sus apuntes biográficos con la siguiente apreciación: «Góngora, si en todas sus obras se hubiera dejado llevar más del ingenio que del estudio, sería reputado como el más perfecto modelo de los poetas españoles» (34). Con esta opinión, retoma a Lope, pero inserta sus juicios en los parámetros del siglo xIx. Para Castro, como para Durán, Góngora es el responsable de la decadencia de la poesía del siglo XVII. Pero ahora su pecado no se encuentra en haberse abandonado a la inspiración, sino justamente en lo contrario. La teoría de la corrupción, que para los neoclásicos se encontraba en la inclinación de los poetas hacia la fantasía, ahora se comprende de manera inversa. En tanto se dejó llevar por el estudio, Góngora perdió de vista la expresión sincera del alma en un mar de formalidades.

3. Lope de Vega fue incluso más severo de lo que esta cita permite ver. Le criticó a Góngora que abusara del modelo latino ( no es enriquecer la lengua dejar lo que ella tiene propio por lo extranjero, sino despreciar la propia mujer por la ramera hermosa» (Martínez Arancón 1978: 124)), y, sobre todo, lo censuró en tan- to le dio una importancia abusiva al ornato, como observa en el soneto con el que concluye la carta que citó Castro: «Más de tu Soledad el eco adoro/ Que el alma y voz del lírico portento,/ Pues tu solo pusiste al instrumento/ Sobre trastes de plata cuerdas de oro» (1978: 116-126). 
Para Castro, esto lo acerca a la locura. En la introducción biográfica sobre el poeta, el crítico recuerda que Jusepe Martínez comparaba a Quevedo con el Bosco y a Lope con Lucas Jordán. De igual modo, «Góngora, que lloró en tenebrosos versos la muerte del pintor Dominico Greco, merece el nombre del Greco de la poesía» (36) ${ }^{4}$. En Voyage a Spagne (1845), Theophile Gautier dio una imagen cercana a la que Castro propuso sobre el pintor y el poeta. En Toledo, Gautier visitó la iglesia del hospital del Cardenal, donde se encontraban dos cuadros del Greco. Gautier confiesa haberse quedado asombrado y presenta a partir de ellos una breve semblanza. Según sostiene, Domenico Theotocupuli, que fuera de España era apenas conocido, desde el principio había vivido horrorizado de que lo identificaran como un simple imitador del Tiziano. Esta preocupación lo llevó a los extremos y los caprichos más barrocos («cette préoccupation le jeta dans les recherches et les caprices les plus baroques» (1856: 171)). Con estas ideas, Gautier describe los dos cuadros de la iglesia del Cardenal. El primero representa una Sagrada Familia y, aunque tiene características singulares, a primera vista se lo tomaría por un Tiziano. El trabajo que le llevó, y este resultado, le sirven a Gautier para especular sobre su salud mental: «le peu de raison qui restait au Greco dut chartier tout à fait dans le sombre océan de la folie, après avoir achevé ce chefd'oeuvre» (171). El otro cuadro, cuyo tema es el bautismo de Cristo, pertenece a la segunda manera, que, según Gautier, el Greco produjo desde la locura:

L'autre tableau, dont le sujet est le Baptême du Christ, appartient tout à fait à la seconde manière du Greco : il y a des abus de blanc et de noir, des oppositions violentes, des teintes singulières, des attitudes strapassées, des draperies cassées et chiffonnées à plaisir; mais dans tout cela règment une énergie dépravée, une puissance maladive, qui trahissent le gran peintre et le fou de génie (172).

La comparación de Castro entre Góngora y el Greco apunta a una misma dirección. Si Luzán había identificado el siglo Xviı con el desarreglo o la confusión, el rescate de la poesía dramática y el romancero terminó de correr esa caracterización a Góngora y a los poetas de la «secta culterana». Pero en este corrimiento la idea de locura también se transformó. En Luzán se trata de una fantasía descarriada de las reglas y las formas que podía proporcionarle la razón. En Gautier y Castro, esta concepción da un giro notable. En el Greco y Góngora, los desvíos de la segunda manera fueron causados por una búsqueda de originalidad respecto

4. El rescate del Greco coincidió, aproximadamente, con la definitiva rehabilitación de Góngora. Según Mainer, hasta el fin de siglo su olvido había sido casi absoluto. El primer rescate es de esa época: en 1894, «el pintor catalán Santiago Rusiñol consagró su segun- da Festa Modernista a la reivindicación de El Greco»; pero tenemos que llegar a 1902 para que el Museo del Prado le dedique la primera exposición retrospectiva, y a 1921 para que el mismo museo abriera una sala permanente para el pintor (Mainer 2010: 55). 
de los hallazgos del pasado. Esto, que los acerca a la locura, los llevó a poner el énfasis en aquellos aspectos que destacaran la forma, convirtiéndola en el tema central. En el Greco, el abuso del blanco y del negro, los contrastes violentos y los tintes raros; en Góngora, los excesos retóricos y la musicalidad.

En la Historia de las ideas estéticas en España (1885-1889), Marcelino Menéndez Pelayo ratificó este tipo de lectura. En el espacio que dedica a la literatura del siglo Xvir acepta la idea de Luzán de que ésta se había movido con libertad. Pero Menéndez Pelayo entiende que esa libertad era sumamente estimable, porque revelaba que los escritores del pasado no sólo se habían orientado de acuerdo con los modelos clásicos, sino que habían buscado vincular esos preceptos con las condiciones nacionales. Así, la literatura española se caracterizó por adecuarse al principio de la imitación, pero no tuvo demasiados remilgos en abandonar, en el teatro, las unidades de tiempo, lugar y acción. Con esto, la Historia de las ideas estéticas celebró la creación de una poética nacional.

Menéndez Pelayo retomó el esquema modificado de la teoría de la corrupción que habían elaborado Durán y Castro. Según sostiene en la Historia de las ideas estéticas, la verdadera literatura nacional se encuentra en aquellas obras en las que su autor logró articular la erudición y la genialidad estética con los gustos y los intereses populares. El Renacimiento fue, en este sentido, un período floreciente. Cultos y a la vez populares fueron Ariosto, Shakespeare y Cervantes. Pero después de estos grandes escritores los criterios se bifurcaron. De un lado floreció el teatro del período, iniciado de manera genial por Lope de Vega, que transformó la poesía épica popular en poesía dramática, y a partir de entonces fue configurando un teatro verdaderamente nacional; del otro lado emergió una literatura cortesana, convencional, afectada, formal, que «voluntariamente se aisló del arte popular, cegó las vivas fuentes de la poesía indígena de cada pueblo, formó en las Academias y en los palacios de reyes y magnates una aristocracia intelectual» (1940: 328). Para Menéndez Pelayo, esta desviación responde a una actitud generalizada en Europa, que lanzó sobre ella una «plaga peor que la langosta, la plaga de las églogas, de los madrigales, de los sonetos, de las canciones metafísicas al modo toscano, de las novelas pastoriles, de las farsas alegóricas», una plaga que, "fuera de la elegancia de la forma, conseguía reunir los peores defectos de dos decadencias literarias, la decadencia alejandrina y la decadencia tolosana, la falsa antigüedad y la falsa Edad Media» (328-329). Menéndez Pelayo ya no ve a Góngora como alguien que había bordeado la locura, sino que, de manera más directa y concreta, su error se encuentra en el artificio extremo y la falta absoluta de ideas: «Góngora, pobre de ideas y riquísimo de imágenes, busca el triunfo en los elementos más exteriores de la forma poética, y comenzando por vestirla de insuperable lozanía, e inundarla de luz, acaba por recargarla de follaje y por abrumarla de tinieblas» (326). Para Menéndez Pelayo, su opuesto simétrico es Quevedo: «no hace versos por el solo placer de halagar la vista con la suave mezcla de lo blanco y de lo rojo: acostumbrado a jugar con las ideas, las convierte en dócil instrumento suyo, y se pierde por lo profundo como otros por lo brillante» (326). En lugar de la locura, la Historia 
de las ideas estéticas ve en Góngora y Quevedo dos expresiones de la decadencia literaria y cultural. Pero, al igual que Castro, comprende esta cuestión a partir de la visión invertida de la teoría de la corrupción. Góngora y Quevedo son dos decadentes, porque en lugar de abandonarse a la inspiración y a los gustos del público, se perdieron en el estudio y la formalidad o la excesiva acentuación de las ideas.

Esta constelación (genio nacional de Lope y locura o decadencia de Góngora) será central para la época del modernismo. Como veremos en el siguiente apartado, la clave de la recuperación de Góngora se encuentra en la reivindicación de la decadencia y la locura como los dos ejes para comprender la creación.

\section{Góngora y el modernismo}

Para reivindicar el teatro del siglo XvII, Durán ratificó y a la vez transformó el valor de los prejuicios neoclásicos. Rescató el aspecto no racional de la poesía, defendió la falta de adecuación a la imitación de la naturaleza, la inclinación ante el gusto popular y la ruptura con las reglas de la Antigüedad Grecolatina. Con esta vuelta de tuerca a las ideas del neoclasicismo sobrescribió un nuevo prejuicio, esta vez romántico, que supone que el teatro del 1600 constituye uno de los momentos clave para la conformación de la tradición nacional. Parte de la recuperación del Barroco que se dio durante los años de la Primera Guerra Mundial sería incomprensible sin esta transformación. Ahora bien, esta idea no podría haber sido formulada sin una transformación de la teoría de la corrupción. Como vimos, entre Durán y Menéndez Pelayo se llegó a la conclusión de que efectivamente la literatura del siglo XviI había entrado en una etapa de decadencia. Pero ésta se desplazó a los poemas mayores de Góngora y sus seguidores. A su vez, se consolidó la idea de que la corrupción se debía a que esos poetas, en lugar de expresar el alma, habían abusado del estudio, los artificios y la formalidad. Así, gran parte de la obra de Góngora quedó marcada por los estigmas del formalismo (Durán), la locura (Castro) y la decadencia (Menéndez Pelayo). En síntesis, el siglo XIX impuso dos prejuicios: la idea de genio nacional, asociada al teatro, y la locura o la decadencia, ligada a la obra del poeta cordobés.

La reivindicación de Góngora, por parte del modernismo, es una consecuencia de la valoración de estos prejuicios a partir del proceso de jerarquización de los componentes no racionales para comprender la literatura. Un rasgo característico en este sentido se encuentra en el cambio de actitud hacia los elementos formales y sensoriales del poema (la melodía, el ritmo o el empleo de imágenes). Aparte de la valoración intrínseca de estos elementos, el modernismo incluyó ese renovado interés en una preocupación muy marcada por establecer vínculos entre la literatura y el resto de las artes. No hay que olvidar, en este sentido, la importancia que hasta en los títulos cobró ese tema (recordemos, por ejemplo, los nocturnos de José Asunción Silva, el famoso «Sonatina» de Rubén Darío y los «Retratos» de Cantos de vida y esperanza). En igual sentido, es fundamental la cuestión de la unidad 
de las artes y su impacto en los aspectos retóricos. Como observa Cathy Jrade, la «sinestesia, que a menudo se considera una de las características diferenciales más importantes tanto de la poesía simbolista como de la modernista, también apoya la interacción entre las artes gráficas, verbales y auditivas» (2006: 43). Como observa Egido, la reivindicación del Barroco, a fines del siglo XIX, se caracterizó por situar su punto de vista en las artes plásticas, ahondando por lo tanto los rasgos sensoriales (2009: 7). Ciertamente, esto puede entenderse por la importancia que cobraron los ensayos de Wölfflin, pero también, como observa Egido, por este interés que los modernistas pusieron en la unidad de las artes, que forma una constelación con la relectura de Góngora y la importante transformación positiva de los estigmas de la locura, la decadencia y la sensualidad.

Rubén Darío se ubica en el centro de esta red de cuestiones. En 1899, durante su segundo viaje a España, el poeta participó de las celebraciones del centenario de Velázquez con el famoso tríptico de sonetos «Trébol», que luego recogió en Cantos de vida y esperanza (1905). En ese texto, en lugar de hacer una poesía encomiástica tradicional, le cede la voz a Góngora, quien en un soneto en endecasílabos remarca la gloria de Velázquez y aprovecha para contarle sus cuitas por haber sido olvidado. Para mayor tristeza, destaca que el único brillo que le queda es el recuerdo del día en que Velázquez pintó su retrato. El pintor, por su parte, toma la palabra en el segundo soneto, también en endecasílabos, y lo reconforta, anunciándole que «ya empieza el noble coro de las liras/ a preludiar el himno a tu decoro» (1986: 39). Finalmente, en el tercer poema, ahora en alejandrinos, Darío hace suyo ese presagio, ratificando que está a un paso de la consagración. Como es de esperar, el poeta recupera en el primer soneto varios de los rasgos estilísticos de Góngora. El hipérbaton y el verso bimembre, así como también el comienzo, que recuerda el famoso "Mientras por competir con tu cabello», son marcas inconfundibles:

Mientras el brillo de tu gloria augura

Ser en la eternidad sol sin poniente,

Fénix de viva luz, fénix ardiente,

Diamante parangón de la pintura,

De España está sobre la veste obscura

Tu nombre, como joya reluciente;

Rompe la Envidia el fatigado diente,

Y el olvido lamenta su amargura.

Yo en equívoco altar, tú en sacro fuego,

Miro a través de mi penumbra el día

En que el calor de tu amistad, Don Diego,

Jugando de la luz con la armonía,

Con la alma luz, de tu pincel el juego

El alma duplicó de la faz mía (38-39).

Como puede leerse a simple vista, Darío reinscribe los temas de la representación y el retrato, tan característicos del siglo XviI, en la unidad modernista de las artes plásticas y la literatura. Por otra parte, el poema consagró para la época 
la ecuación entre Góngora, el Barroco y el modernismo rubendariano. En «La nueva generación de novelistas» (1904), Emilia Pardo Bazán rescata la línea austera y de influjos neorrománticos española del "pseudo-gongorismo afrancesado que corrompe a algunos escritores de América» (2010: 616). En el mismo sentido, en "Para un estudio de la literatura española», fechado en 1914, Antonio Machado hace un listado de escritores a partir de la idea de que la poesía debe expresar la «pura emoción». Por lo tanto se pronuncia en contra de los «poetas que pretenden manejar imágenes puras (limpias de concepto (!) y también de emoción), sometiéndolas a un trajín mecánico y caprichoso, sin que intervenga para nada la emoción» (1973: 786). Propone luego la siguiente identificación, empleando tal vez por primera vez el concepto: «Neobarroquismo: Rubén Darío» (786).

Por cierto, Darío no continuó esta perspectiva «neobarroca». Las razones pueden ser muchas. Las impugnaciones de Machado y otros escritores españoles deben haber tenido su peso. Además, tras el inicio del nuevo siglo Darío abandonó la poesía lujosa de Prosas profanas por la mucho más austera y americanista que ya se lee en los poemas más tardíos de Cantos de vida y esperanza. De todos modos, al rescatar a Góngora como marginal y reinscribir la representación del Barroco en la sinestesia de fin de siglo, compuso una imagen del poeta que será fundamental para el siglo xx. En primer lugar, Darío aceptó los prejuicios sobre la decadencia, la locura y el formalismo que se habían configurado sobre el poeta entre el siglo XVIII y fines del xIx. En segundo término, según una transformación que excede su lectura puntual de Góngora, cambió el signo que pesaba sobre esos ejes interpretativos. Se puede caracterizar este proceso, en términos generales, a partir de lo que Mainer denomina las "máscaras del decadentismo», es decir, esas apelaciones a rasgos marginales, como la locura, la enfermedad, el crimen, la barbarie, mediante las cuales los escritores asumieron un estilo, un gesto y aun una moda en el vestir con las que buscaron diferenciarse del resto de la sociedad. Escribe Mainer: «Se trataba siempre de llamar la atención» (2010: 106), a lo que podría agregarse que se trataba también de buscar aquellos síntomas que, dispersos en la red social, son los agujeros que la ponen en cuestión.

Esta lectura de Darío, en la que se integran la revalorización de Góngora y la transformación de los prejuicios neoclásicos y románticos, se inscribe en un proceso complejo que tiene múltiples aristas. Podemos destacar, entre otros, la accidentada historia de la recuperación del poeta y, de manera inseparable, el lugar que ocupó España para algunos escritores franceses. El primer aspecto es muy conocido. La imagen de Góngora como un escritor maldito, olvidado, decadente y, por lo mismo, interesante, no le pertenece a Darío, sino que Darío la encontró durante su visita a París, en 1893, seis años antes de redactar "Trébol». En esa oportunidad, pudo ver que Verlaine y Moreas conocían a Góngora y Calderón de la Barca. Como los franceses, el escritor rescató a Góngora porque se trataba de un autor maldito. Por otra parte, ése era también el prejuicio que se había impuesto en España en el siglo xIx. Como vimos, Góngora era un escritor decadente, según Menéndez Pelayo, o un poeta que había bordeado la locura, de acuerdo con Cas- 
tro. De esta manera, Darío corrió el eje de lectura del poeta cordobés. Tomó las ideas de decadentismo, locura, formalismo e incluso, como veremos, de barbarie, y las convirtió en marcas positivas, en tanto las entendió como los síntomas interesantes de la modernidad.

Este proceso de transformación de los prejuicios se puede reconstruir también a partir de la imagen de España en el extranjero. Como señala Rafael Ferreres, Verlaine se interesó por Góngora en tanto desde el romanticismo España se había puesto de moda entre los escritores franceses y tal vez entre la gente de la alta sociedad $(1975)^{5}$. En ella se enrolaron Chateaubriand, Vigny, Musset y Víctor Hugo, quien en el Prefacio a Cromwell se había extendido en citas de españoles como Lope de Vega y Tomás de Iriarte, y cuyo hermano Abel había traducido el romancero heroico español en 1822. Lo mismo había sucedido con Theophile Gautier. Su hispanofilia lo llevó a cargar con una máquina de daguerrotipo y padecer largas jornadas en diligencias y galeras tras los Pirineos para captar en Voyage a Spagne algo de la esencia de aquel país. Pero lo más importante es que buscó en esas tierras un país romántico y primitivo, que todavía no estuviera contaminado por la civilización parisina. A la entrada de Espańa confiesa qué es lo que buscaba, sin dejar de anotar el temor de que ese deseo se viera de pronto disuelto por una más prosaica realidad: «Encore quelques tours de roue, je vais peut-être perdre une de mes illusions, et voir s'envoler l'Espagne de mes rêves, l'Espgna du romancero, des ballades de Victor Hugo, des nouvelles de Mérimée et des contes d'Alfred de Musset» (1856: 17). Se desengañó en Madrid, porque se habían importado las modas francesas y había remedos de la vida parisina; en cambio, encontró su sueño en las actividades y los lugares románticos: las corridas de toros, la gente de los pueblos, las iglesias y catedrales, plagadas de reliquias, santorales y cuadros impactantes por lo emotivos. Si bien el balance de Gautier fue más bien negativo, en tanto consideró que España había perdido mucho del aire romántico que tenía, lo conservaba en su primitivismo, y era precisamente ese primitivismo el que hacía atractivo el país. Expandió, por ejemplo, ese ambiguo elogio a partir de la excelencia de la alfarería, el arte del mimbre y la manera de enjaezar las bestias de carga, tres aspectos en los que se destacaba España y que le resultaban admirables, a pesar de que revelaban para él exactamente lo contrario de lo que esperarían los españoles:

Il y a trois choses qui sont pour moi des thermomètres précis de l'état de civilisation d'un peuple : la poterie, l'art de tresser soit l'oiser soit la paille, et la manière de har-

5. Esta moda francesa, que le prestaba a Espańa una admiración absolutamente ambigua, a la larga fue reconocida por algunos escritores españoles. Como recordó Leopoldo Zea, el clima post '98 empujaba a los intelectuales a preguntarse finalmente por el país, lo cual los llevó a buscar una modernidad que fuera nacional y que por lo tanto constituyera el resultado de un desarrollo interno, cuyo punto de partida debía ser, necesariamente, este atraso que tanto le gustaba a Gautier (Zea 1995: 28-32). 
nacher les bêtes de somme. Si la poterie est belle, pure de formes, correcte comme l'antique, avec le ton naturel de l'argile blonde ou rouge; si les corbeilles et les nattes sont fines, merveilleusement enlacées, relevées d'arabesques de couleurs admirablement choisies ; si les harnais son brodés, piqués, ornés de grelots, de hpuppes de laine, de dessins du plus beua choix, vou pouvez être sûrs que le peuple est primitif et trèsvoisin encore de l'état de nature : des civilisés ne savent faire ni un pot, ni une natte, ni un harnais (1856: 105).

Darío se hizo eco de este rescate de la barbarie. Escribe en la necrológica sobre Leconte de Lisle, que publicó en La Nación y luego recopiló en Los raros:

El más griego de los artistas, como le llamara un joven esteta, cantó a los bárbaros, ciertamente. Como había en su reino poético, suprimido todo anhelo por un ideal de fe, la inmensa alma medieval no tenía para él ningún fulgor; y calificaba la Edad Media como una edad de abominable barbarie. $Y$ he aquí que ninguno entre los poetas, después de Hugo, ha sabido poner delante de los ojos modernos, como Leconte de Lisle, la vida de los caballeros de hierro, las costumbres de aquellas épocas, los hechos y aventuras trágicas de aquellos combatientes y de aquellos tiranos; los sombríos cuadros monacales, los interiores de los claustros, los cismas, la supremacía de Roma, las musulmanas barbaries fastuosas, el ascetismo católico, y el temblor extranatural que pasó por el mundo en la edad que otro gran poeta ha llamado con razón, en una estrofa célebre, «enorme y delicada» (1952: 31-32).

Pero para el fin de siglo la barbarie había adquirido un segundo sentido. Gautier todavía usaba el concepto como sinónimo de atraso nacional. Sin embargo, su ambigua admiración hacia España anuncia un significado complementario. Gautier cruzó los Pirineos para ver un paisaje romántico, pero también para encontrar allí la verdad primigenia del hombre y las organizaciones humanas. En este sentido, a lo largo del siglo XIx la barbarie vivió lo que podríamos llamar un proceso de interiorización. Pasó del país atrasado a la verdad perdida, dejó de ser lo Otro del progreso para convertirse en el hueso duro de la sociedad.

Darío asumió este segundo sentido. En Los raros, compara a Leconte de Lisle con un nuevo Pan en busca de la armonía, a quien le salió al encuentro el dios civilizador Apolo, recibiendo de él la lira. Retoma, así, la oposición que Nietzsche había establecido con lo apolíneo y lo dionisíaco. Darío se apropia de ese tema (que como interpretación del siglo XVII será fundamental para buena parte de la crítica del xx) y lo interpreta a través de una insistencia en esa verdad primigenia del hombre que son las pulsiones sexuales. Esto tiene una gran importancia tanto para su lectura de Góngora como para su admiración de Verlaine. En Los raros (1905) dice por ejemplo que en Verlaine «aumentaba su lujuria primitiva y natural a medida que acrecía su concepción católica de la culpa» (49). En "Cantos de vida y esperanza» habla de Góngora y Verlaine a través de la sensualidad:

Como la Galatea gongorina

Me encantó la marquesa verleniana 
Y así me juntaba a la pasión divina

Una sensual hiperestesia humana (1986: 11).

Este desplazamiento de la barbarie nos lleva a la locura. Como se sabe, el fin de siglo asistió a un intenso debate sobre las relaciones entre la enfermedad mental y la creación literaria. Esto es lo que hizo que los modernistas mantuvieran relaciones ambiguas con Max Nordau, Cesare Lombroso y Pompeyo Gener. Los tres calificaron a los escritores contemporáneos a partir de categorías psiquiátricas, considerando que sus obras eran el fruto de su desviación. Como señala Mainer, en Literaturas malsanas Gener estableció un amplio cuadro de degeneraciones, donde se criticaban «las «Enfermedades indígenas» del intelecto, todas castellanas: el «retoricismo» dominante, el "criticonismo» que ha convertido la crítica en comadreo [...] y el "cronicronismo" que pretende reemplazar el análisis por la erudición vana» (2010: 27). Si bien muchos escritores rechazaron este tipo de cuadros patológicos, mantuvieron con ellos una relación ambigua. En De sobremesa (1925), el colombiano José Asunción Silva comparó Degenerados de Nordau (1892) con el Diario de María Bashkirtseff. Juan Fernández celebra los compulsivos proyectos de la tuberculosa y desprecia al psiquiatra. Pero igual lo necesita, porque con Nordau puede demostrar que el genio se aparta de la norma social. La misma ambivalencia se encuentra en Darío. Le dedicó a Nordau una extensa y humorística crónica descalificatoria, uno de cuyos pasajes se cita a continuación:

Max Nordau no deja un solo nombre, entre todos los escritores y artistas contemporáneos de la aristocracia intelectual, al lado del cual no escriba la correspondiente clasificación diagnóstica: «imbécil», «idiota», «degenerado», «loco peligroso». Recuerdo que una vez, al acabar de leer uno de los libros de Lombroso, quedé con la obsesión de la idea de una locura poco menos que universal. A cada persona de mi conocimiento le aplicaba la observación del doctor italiano, y resultábale que, unos por fas, otros por nefas, todos mis prójimos eran candidatos al manicomio (1952: 170).

Pero Los raros lleva la marca de Nordau. Si los escritores que hay en sus páginas son raros, es precisamente porque están fuera de la normalidad. Incluso Darío le otorgó cierta veracidad a la psiquiatría, confirmando aunque sea tácitamente que el genio creador bordea la locura: «La psiquiatría -escribe Darío- pone su lente práctico en regiones donde solamente antes había visto claro la pupila ideal de la poesía» (171). Además, destacó algunas de las tesis de Nordau que tienen una particular importancia para su idea de la locura y el genio creador. Subrayó, por ejemplo, que lo que le permitía al psiquiatra calificar a ciertos artistas de enfermos mentales era la importancia que le concedían a la música en detrimento de la razón: «Es una particularidad de los idiotas tener gusto por la música [...] por tanto, los que se entregan a ella son o están próximos a ser degenerados» (174). Darío, que amó a Wagner y manejó el verso con admirable musicalidad, debe haber sonreído al verse indirectamente mentado como idiota y degenerado. Pero si 
bien estas etiquetas eran ridículas, Nordau sí ratificaba que el artista iba por fuera de las normalidades de la sociedad.

¿Todo esto se encuentra en «Trébol»? Sin duda que no. Pero «Trébol» es el emergente de esta transformación de los prejuicios. Darío se interesó por Góngora en tanto los escritores franceses lo habían calificado como un maldito, o, en sus términos, como un raro. A su vez, se habían transformado los conceptos negativos de barbarie, formalismo, decadentismo y locura, que también afectaban a Góngora. Según el proceso de jerarquización de los componentes no racionales para comprender la literatura, de pronto pasaron a ser marcas interesantes, más que positivas, síntomas sociales de los cuales tenía que ocuparse la literatura. En fin, la unidad de las artes, con el peso que esto le confiere a los componente formales de la poesía, impulsó por su parte esta relectura del pasado.

Pero si no están explícitamente enumerados en «Trébol», toda esta enorme transformación caracteriza la época y se encuentra plasmada, con una notable explicitud, en Lo barroco. En ese volumen, Eugenio D'Ors recopila varios textos, muchos de ellos muy tempranos, en los cuales se explaya sobre las características positivamente marginales del Barroco. En "Churriguera» (1908), D’Ors recuerda a Zenón de Elea, a quien identifica directamente como un «filósofo maldito». Otro tanto le corresponde a Américo Vespucio: «un explorador maldito [porque] queremos hacerle pagar caro la ventaja de haber legado su nombre al Continente descubierto por Cristóbal Colón». Aparte de Churriguera, el más significativo de sus ejemplos es Góngora. Considera al poeta cordobés como un «poeta maldito, [que] soporta, como la noción médica de «artritismo», el padrinazgo de las más variadas enfermedades» (1993: 23).

En el mismo sentido, D'Ors retoma el primitivismo. En «El Widermann», el ensayista observa que el estilo de la civilización se llama clasicismo. En consecuencia, el estilo de la barbarie se identifica con el Barroco. En el más extenso «De Robinson a Gauguin» (1925) se ocupa con mayor profundidad de este último aspecto. En principio, en un sintético acápite sobre Rousseau, recuerda la tesis de la superioridad «del estado natural en el hombre respecto de las conquistas de su civilización» (25). Para D’Ors, ésta fue la gran innovación del romanticismo. Pero el romanticismo fue la realización del «eón» barroco a fines del siglo xviII. No sorprende, en este sentido, que D’Ors haya explicitado también la identificación del Barroco con la locura. Escribe el ensayista en el trabajo recién citado:

Imaginemos una infancia educada por locos... Si bien se mira, ¿no ha ocurrido que, durante más de una centuria, la infancia entera de todos los países y de todas las condiciones sociales haya sido, más o menos indirectamente, educada por un loco: por Juan Jacobo Rousseau?

Una sociedad como la que evoco -o imagino- tenderá necesariamente, en su expresión, en su estilización, al empleo de las formas características de lo barroco (1993: 52).

Como demostró Foucault, la locura, tal cual la conocemos, apareció tras la Revolución Francesa. Antes de esa fecha, como podemos verlo en Luzán, era el 
lugar del error, lo opuesto de la verdad, que se encontraba en la razón universal. Si la barbarie pasó de ser lo otro del progreso para convertirse también en lo que todo hombre y toda sociedad tienen en su interior, del mismo modo la locura dejó de ser el error para convertirse en la verdad más profunda del ser humano. Según Foucault, «El loco revela la verdad elemental del hombre», porque lo reduce «a sus deseos primitivos, a sus mecanismos simples», presentando su «infancia cronológica y social»; pero a la vez, la locura es una enfermedad del exceso de civilización y «empieza con la vejez del mundo, y cada rostro que la locura adopta en el curso del tiempo habla de la forma y la verdad de esta corrupción» (1992 II: 275). Síntoma central del fin de siglo, en la locura coinciden la barbarie y el fin de los tiempos, época en la cual el hombre se siente aplastado bajo el peso de la civilización.

Con el rescate de "Trébol», Góngora quedó colocado cerca de estas ideas. Como pudimos comprobar en D'Ors, la época del modernismo confirmó y transformó los prejuicios del neoclasicismo y los que se le impusieron al poeta durante el siglo xIX. Pero a diferencia de lo sucedido con Lope de Vega, no se trata de que una idea como lo popular cambiara de signo. Por el contrario, los prejuicios de locura, barbarie, formalismo y decadencia no se convirtieron en ideas simplemente positivas. Más bien, la valoración pasa porque de pronto tuvo interés que el arte se vinculara con esos núcleos problemáticos, esas verdades recónditas que la cultura ha buscado esconder. En este sentido, se puede decir que Góngora resurgió plenamente cuando los prejuicios que pesaban sobre él dejaron de ser ejes interpretativos para convertirse en los síntomas del hombre y la cultura.

\section{Conclusión: el desplazamiento conceptual}

Con la descripción de Darío y el modernismo podemos dar por concluido este trabajo. Si bien se necesita un análisis detallado de otros autores, creo que demuestra la plausibilidad de lo que llamé la hipótesis hermenéutica y la correspondiente valoración de los prejuicios para comprender la historia de la interpretación y la posterior reivindicación de la cultura del siglo XVII. El proceso puede sintetizarse a partir de las importantes referencias con las que Serés apuntala la suerte de la palabra "fantasía». Como vimos, hubo una inversión de los términos manejados por Luzán. La razón perdió terreno en el campo de la estética, a la par que lo ganó la fantasía o los conceptos a ella asociados. Si tomamos como referencia a Durán, a principios del siglo XIx, y a Menéndez Pelayo, al finalizar esa centuria, los prejuicios neoclásicos se vieron invertidos en su valoración. Así, se reafirmó que la poesía dramática del 1600 era anticlásica, inverosímil, no racional y popular, pero estos cuatro valores se convirtieron en ideas positivas, en la medida en que se asociaron al concepto romántico del genio nacional, en el cual el componente sentimental tiene un protagonismo absoluto. En igual sentido, el asenso de la fantasía supuso una transformación de la teoría de la corrupción. Primero la decadencia se desplazó hacia Góngora. Luego cambió en términos conceptuales: 
dejó de comprenderse como un abuso de la imaginación, para identificársela en cambio a partir de un abuso de los componentes formales y sensuales y aun como un desmedido apoyo en la erudición. En este sentido, al culminar el 1800 se prepararon dos nuevos prejuicios. En primer lugar, la idea de que el teatro del siglo XVII constituye uno de los emergentes más importantes del genio nacional; en segundo término, la sentencia de que Góngora se había inclinado peligrosamente a esos márgenes que son la decadencia, la locura y aun la barbarie. Como vimos, a partir de la valoración positiva de esos prejuicios, durante el modernismo, Góngora quedó asociado a los síntomas de la modernidad.

Esta historia explica en parte la imagen que el siglo xx se hizo del xvII. Como dije en la primera parte de este trabajo, la crítica de esa época puede comprenderse a partir de dos tipos de lectura. Un grupo, cuyo ejemplo máximo es el escritor Severo Sarduy, responde a lo que llamé una "hipótesis del retorno", en tanto considera que el Barroco constituye un espejo para comprender la contemporaneidad; otro grupo, representado por Maravall, está ligado a una "hipótesis historicista», según la cual ese vasto proceso cultural es inseparable de las características históricas del 1600 europeo. Ahora bien, los autores considerados en esa primera parte coinciden en tres ideas centrales: el Barroco es la expresión cultural de una crisis, constituye el comienzo de lo que llamamos modernidad y en él se encuentra por primera vez un sujeto moderno, caracterizado por la escisión o la conciencia de los límites infranqueables ante los que se enfrenta su voluntad. Si bien el breve y fragmentario repaso histórico que propuse en este texto necesita enriquecerse más, se puede decir al menos en parte que estas tres ideas, e incluso que los dos tipos de lectura, dependen de los desplazamientos conceptuales a los que se hizo referencia a través de la instauración y cambio de valoración de los prejuicios sobre el siglo XviI.

Como señala Rico (2005), muchos de ellos aparecieron por primera vez en la polémica en torno a Góngora. Pero como en este texto no se ha hecho referencia a ella, se debe concluir que estos tres ejes interpretativos se remontan al neoclasicismo y son el resultado de las transformaciones semánticas operadas por los críticos y escritores hasta el filo del 1900. En primer lugar, debemos referirnos al Barroco como comienzo de las tradiciones nacionales y, por lo tanto, de la modernidad. La idea se encuentra, como vimos, en el romántico Agustín Durán. En segundo término, la identificación del Barroco como una cultura de la crisis se encuentra en los rescates de Benjamin y Weisbach y tiene su formulación más clara en Maravall. También en este caso su antecedente lejano se remonta a la teoría de la corrupción del siglo XviII. Por consiguiente, si es claro que la cuestión de la crisis surge de una lectura de los documentos, al mismo tiempo es el resultado del largo proceso por el cual se transformaron los prejuicios iniciales del neoclasicismo. Otro tanto sucede con la idea del sujeto escindido. Si por una parte el personaje barroco está en muchos casos elaborado en base a la contradicción, por la otra el desplazamiento del período hacia los componentes no racionales que propuso el neoclasicismo y el rescate posterior en base 
a la transformación positiva de lo irracional contribuyeron en gran medida a esa imagen de que en el Barroco se presenta por primera vez una fragmentación del hombre, entre la conciencia y los impulsos soterrados.

Independientemente de las posibilidades explicativas de la historia de los prejuicios, la perspectiva que acabo de presentar tiene tres utilidades. En primer lugar, este trabajo expone parte de la historia de las ideas que cincelan la imagen histórica que el siglo Xx se forjó del XVII. Por supuesto, este esclarecimiento no impacta, ni para bien ni para mal, en el trabajo específico con los documentos. Pero pone de relieve que el vínculo con el pasado no es simple y a la vez subraya que, como lo vio perfectamente Maravall, la imagen que tenemos del pasado es siempre el producto de las ideas, intereses y necesidades del presente. En segundo lugar, esta investigación en los prejuicios muestra que la imagen del Barroco comienza a elaborarse al menos desde el siglo xvin y va acompañando el proceso histórico de la modernidad. En este sentido, podríamos decir que, si desde cierto ángulo puede entenderse que ese complejo y multifacético proceso histórico de la literatura comienza en el 1600, desde otro ángulo podría considerarse que, en realidad, el comienzo se encuentra con la interpretación de esa época, a partir del neoclasicismo. Como el Barroco ocupó durante mucho tiempo el margen de la razón, es admisible comprender la imagen cambiante que tuvo a lo largo de la historia como uno de los focos oscuros del proyecto de la Ilustración. Por último, la búsqueda en las bases de los prejuicios sirve para comprender a ese sector de la crítica asociado a la idea de que existe un retorno del Barroco. Si en la historia de la recepción, éste no hubiera quedado identificado, particularmente a través de Góngora, con la decadencia, la locura y la barbarie, tal vez esa comprensión, que sitúa el siglo XviI como un espejo de la contemporaneidad, no hubiera existido. Pero no hace falta adentrarnos en una hipótesis contrafáctica. Porque sin duda podemos afirmar que las relaciones que D'Ors establece entre la locura, la decadencia y el Barroco, la identificación de Lacan con el 1600, basada en su propuesta del sujeto, el trabajo subsidiario de Sarduy o la dimensión sagrada de Lezama Lima, no son ideas que se desprenden de un retorno puro, y sin prejuicios, a los documentos, sino que éstas surgen de la cercanía entre Barroco e irracionalidad que se entabló a partir del siglo xviII. 


\section{Bibliografía}

Berbel Rodríguez, José, Orígenes de la tragedia neoclásica española (17371754): la Academia del Buen Gusto, Sevilla, Universidad de Sevilla, 2003.

Carnero, Guillermo, "Los dogmas neoclásicos en el ámbito teatral», Anales de la literatura española, 10, (1994), 38-77.

Castro, Adolfo, Poetas líricos de los siglos XVI y XVII, tomo I, Madrid, Rivadeneyra, 1854.

D’Ors, Eugenio, Lo barroco, Madrid, Tecnos, 1993.

DArío, Rubén, Los raros. Espasa-Calpe, Buenos Aires, 1952.

- La vida de Rubén Dario, escrita por él mismo, en Autobiografías, Enrique Anderson Imbert, Buenos Aires, Ediciones Marymar, 1976.

- Poesía completa, Ángel Rama, Buenos Aires, Biblioteca Ayacucho, 1986.

Durán, Agustín, Discurso sobre el influjo que ha tenido la crítica moderna en la decadencia del Teatro Antiguo Español, Madrid, Imprenta Ortega y Compañía, 1828.

Egido, Aurora, El Barroco de los modernos. Despuntes y pespuntes, Valladolid, Cátedra Miguel Delibes, Universidad de Valladolid, 2009.

Ferreres, Rafael, Verlaine y los modernistas españoles, Madrid, Gredos, 1975.

Foucault, Michel, Historia de la locura en la época clásica, México, FCE, 1992.

Gadamer, Hans-Georg, Verdad y método I, Salamanca, Sígueme, 1977.

GARCía DE LA CoNCHA, Víctor, «Barroco: categorías, sistema e historia literaria", en Estado actual de los estudios sobre el Siglo de Oro, Manuel García Martín, Salamanca, Ediciones Universidad de Salamanca, 1993.

Gautier, Theophile, Voyage en Espagne, París, Charpentier, 1856.

Glendinning, Nigel, «Lo gótico, lo funeral y lo macabro en la cultura española europea del siglo XVII", Anales de literatura española, 10, (1994), 119-136.

HatzFeld, Helmut, Estudios sobre el Barroco, Madrid, Gredos, 1964.

Hugo, Víctor, Prefacio de Cromwell, Buenos Aires, Editorial Goncourt, 1979.

JRADE, Cathy, "La poesía modernista», en Historia de la literatura hispanoamericana, II, Roberto González Echeverría y Enrique Pupo-Walker, Madrid, Gredos, 2006, 37-94.

López Bueno, Begoña, En torno al canon: aproximaciones y estrategias, Sevilla, Universidad de Sevilla, 2005.

LuzÁn, Ignacio, La poética, Russell Sebold, Madrid, Cátedra, 2008.

Machado, Antonio, Obras. Poesía y Prosa, Buenos Aires, Losada, 1973.

MaIner, José-Carlos, Historia de la literatura española. Modernidad y nacionalismo, Madrid, Crítica, 2010.

Martínez Arancón, Ana, La batalla en torno a Góngora, Barcelona, Antonio Bosch Editor, 1978.

Menéndez Pelayo, Marcelino, Historia de ideas estéticas en España, tomo II, Santander, Consejo Superior de Investigaciones Científicas, 1940. 
PARdo BazÁN, Emilia (1904): «La nueva generación de novelistas y cuentistas en España», en Mainer 2010, 614-616.

Rico, José Manuel, «Algunas consideraciones sobre los procesos de canonización en la preceptiva literaria. Siglo XVII», en En torno al canon: aproximaciones y estrategias, Begońa López Bueno, Sevilla, Universidad de Sevilla, 2005, 141-166.

SERÉs, Guillermo, «El concepto de fantasía, desde la estética clásica a la dieciochesca", Anales de literatura española, 10, (1994), 207-236.

Silva, José Asunción, Obra Completa, Madrid, Colección Archivos, 1996.

Vega y Carpio, Lope Félix de, El arte nuevo de hacer comedias en este tiempo, Juana José Prades, Madrid, Clásicos Hispánicos, 1971.

Velázquez, Luis Josef, Orígenes de la poesía castellana, Málaga, Herederos de D. Francisco Martínez de Aguilar, 1797.

ZeA, Leopoldo, «Ortega, filosofía desde la barbarie», SÁNCHez VIdal, Agustín - Rico, Francisco, Historia crítica de la literatura española, Época contemporánea (primer suplemento), Barcelona, Crítica, 1995. 